Trauma Surgery \& Acute Care Open

\title{
New non-invasive device to promote primary closure of the fascia and prevent loss of domain in the open abdomen: a pilot study
}

\author{
Joao Baptista Rezende-Neto, ${ }^{1,2}$ Bruna Gewehr Camilotti²
}

\begin{abstract}
'Surgery, University of Toronto Faculty of Medicine, Toronto, Ontario, Canada

${ }^{2}$ General Surgery, St Michael's Hospital, Toronto, Ontario, Canada

Correspondence to Dr Joao Baptista Rezende-Neto, Division of General Surgery Trauma, St. Michael's Hospital 30 Bond Street Room 3073B, Toronto, ON M5B 1W8, Canada; joao.rezende-neto@unityhealth. to
\end{abstract}

Received 25 May 2020

Revised 10 September 2020

Accepted 16 October 2020
(C) Author(s) (or their employer(s)) 2020. Re-use permitted under CC BY-NC. No commercial re-use. See rights and permissions. Published by BMJ.

\section{To cite:}

Rezende-Neto JB, CamilottiBG. Trauma Surg Acute Care Open 2020;5:e000523.

\begin{abstract}
Background Primary closure of the fascia at the conclusion of a stage laparotomy can be a challenging task. Current techniques to medialize the fascial edges in open abdomens entail several trips to the operating room and could result in fascial damage. We conducted a pilot study to investigate a novel non-invasive device for gradual reapproximation of the abdominal wall fascia in the open abdomen.
\end{abstract}

Methods Mechanically ventilated patients $\geq 16$ years of age with the abdominal fascia deliberately left open after a midline laparotomy for trauma and acute care surgery were randomized into two groups. Control group patients underwent standard care with negative pressure therapy only. Device group patients were treated with negative pressure therapy in conjunction with the new device for fascial reapproximation. Exclusion criteria: pregnancy, traumatic hernias, pre-existing ventral hernias, burns, and body mass index $\geq 40 \mathrm{~kg} / \mathrm{m}^{2}$. The primary outcome was successful fascial closure by direct suture of the fascia without mesh or component separation. Secondary outcomes were abdominal wall complications.

Results Thirty-eight patients were investigated, 20 in the device group and 18 in the control group. Primary closure of the fascia by direct suture without mesh or component separation was achieved in 17 patients $(85 \%)$ in the device group and only 10 patients (55.6\%) in the control group $(p=0.0457)$. Device group patients were $53 \%$ more likely to experience primary fascial closure by direct suture than control group patients. Device group showed gradual reduction $(p<0.005)$ in the size of the fascial defects; not seen in control group. There were no complications related to the device. Conclusions The new device applied externally on the abdominal wall promoted reapproximation of the fascia in the midline, preserved the integrity of the fascia, and improved primary fascial closure rate compared with negative pressure therapy system only. Level of evidence I, randomized controlled trial.

\section{INTRODUCTION}

Approximately 25\% of trauma patients undergoing emergency laparotomy are ineligible for primary fascial closure at the conclusion of the initial operation. $^{1-5}$ Therefore, purposely leaving the abdominal fascia open has become a key component of damage control laparotomy. ${ }^{6-9}$ The indications to leave the abdominal wall fascia open at the conclusion of a laparotomy can be separated into three categories: anatomic, physiologic and logistic reasons. ${ }^{9}{ }^{10}$ Anatomic reasons pertain to the inability to bring the fascial edges together at the index operation or creating unwarranted risks of abdominal compartment syndrome. Physiologic reasons relate to systemic dysfunction, and logistic reasons refer to anticipated surgical reinterventions in the abdomen. ${ }^{10} 11$ Leaving the abdomen open with a temporary abdominal coverage device preserves the integrity of the abdominal wall fascia and facilitates repeated abdominal explorations. Ideally, the fascia is closed through primary suture during the last phase of the staged laparotomy approach. ${ }^{12-14}$ However, there is significant variability in primary fascial closure rates reported in the literature. ${ }^{12}{ }^{13}{ }^{15-17}$ A systematic review and meta-analysis involving more than 3000 patients reported that the average rate of primary fascial closure was only $62 \% .^{12}$

The method of temporary abdominal coverage used during the initial phases of the staged laparotomy approach is an important factor for successful fascial closure. ${ }^{18-21}$ Generally, primary fascial closure rates greater than $80 \%$ have been reported with vacuum-assisted devices in combination with methods that provide gradual midline dynamic tension of the abdominal wall fascia. ${ }^{13-15}{ }^{22-30}$ In contrast, attempts to medialize the fascia using only vacuum-assisted devices are limited, and excessive negative pressure could potentially damage intra-abdominal viscera. ${ }^{14}$ Therefore, a combined approach enhances the approximation of the fascia and prevents progressive loss of abdominal domain by counteracting lateralization of the abdominal wall muscles. However, current techniques to medialize the fascial edges entail suturing prosthetic material to the fascia followed by gradual fascial reapproximation through several reoperations. ${ }^{713} 151623242631-34$ Moreover, those techniques generally engage only the rectus abdominis muscle and the rectus sheath. Therefore, significant opposing force generated by the lateral components of the abdominal wall, not encompassed in the process, limits medialization of the fascial edges. Furthermore, excessive traction at the anchoring sites on the fascia frequently results in fascial damage. To tackle those limitations, we developed a novel non-invasive device for gradual reapproximation of the abdominal wall fascia and dynamic splinting of the abdominal wall muscles. We conducted a single-center pilot study to investigate the impact of the new technology on primary fascial closure in the open abdomen. 


\section{METHOD}

A sample size of 40 patients ( $\mathrm{n}=20$ per group) was estimated for this study based on statistical recommendation and relevant feasibility factors. ${ }^{35}$

Open abdomen patients were randomized into two groups. Control group patients underwent standard care with negative pressure therapy system only. Device group patients were treated with negative pressure therapy system in conjunction with the new device for gradual reapproximation of the fascia. The negative pressure system used in both groups was the ABThera Open Abdomen Negative Pressure Therapy System (Kinetic Concepts, San Antonio, Texas, USA). The primary outcome was the proportion of patients with successful closure of the fascial defect by direct suture of the fascia without mesh or component separation techniques. Secondary outcomes were complications linked to the use of the device, predominantly affecting the abdominal wall.

\section{Eligibility criteria and randomization process}

All mechanically ventilated patients $\geq 16$ years of age who had the abdominal wall fascia and the skin deliberately left open at the conclusion of a midline laparotomy for both trauma and acute care surgery were assessed for eligibility by the research coordinator. Exclusion criteria included pregnancy, patients with any loss of the integrity of the abdominal wall (traumatic hernias, extensive debridement), pre-existing ventral hernias, burn patients, and those with a body mass index $\geq 40 \mathrm{~kg} / \mathrm{m}^{2}$.

The intervention given to each patient was determined by a randomization sequence using a validated software (Dacima Software, Montreal, Quebec, Canada). The randomization sequence was administered by sealed randomization envelopes opened by the research coordinator after consent from the legally acceptable representative. Randomization took place within 24 hours after the attending surgeon opted to leave the abdominal fascia open; the device was applied to the patient's abdominal wall within 6 hours of randomization always at the bedside.

\section{Abdominal closure device and installation procedure}

The new device for gradual reapproximation of the abdominal wall fascia consisted of two pairs of rigid polyurethane plates, $20 \mathrm{~cm}(\mathrm{~L}) \times 6 \mathrm{~cm}(\mathrm{~W}) \times 1 \mathrm{~cm}(\mathrm{H})$. Metal hinges joined the plates together forming a pair of clamps (figure 1 ). The bottom plate of

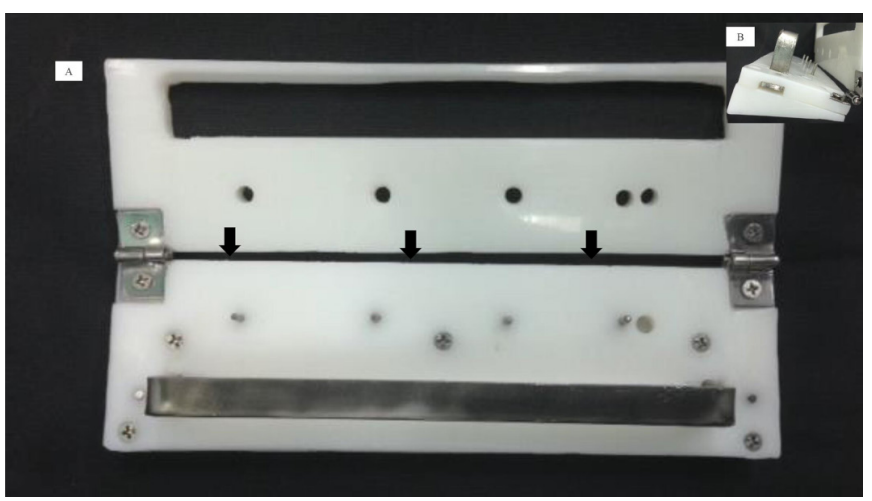

Figure 1 The new device. (A) Front view depicts the bottom and top plates of one clamp with the metal loop and the metal spikes on the bottom plate and the corresponding apertures on the top plate. Arrows show the lateral gap between the top and the bottom plates for insertion of the elastic abdominal binder. (B) Depicts the lateral view of the device. each clamp had four metal spikes to pin the extremity of an elastic abdominal binder, and a metal loop to secure 48 " self-locking nylon cables (Commercial Electric, Atlanta, Georgia, USA). The underside of the bottom plates had an angle of inclination of $20^{\circ}$ to engage the rectus abdominis muscles and promote medialization of the lateral borders of the rectus sheaths (figure 1). The top plates had apertures for the metal loops and the metal spikes located on the bottom plates (figure 1).

The elastic abdominal binder (Ossur, Foothill Ranch, California, USA) passed behind the patient's back centered along the spine. The skin surrounding the fascial defect was protected with silicone foam dressings (Mepilex, Gothenburg, Sweden). The silicone foam dressings were not necessary to maintain the device in place they were applied exclusively to safeguard the skin. Subsequently, the two clamps were positioned parallel to each other on top of the abdominal wall on both sides of the fascial defect. The lateral edges of the clamps were bilaterally aligned with the anterior axillary lines along the rectus abdominis muscles. Afterwards, the elastic binder was stretched taut around the patient's back to engage the lateral abdominal wall muscles. The ends of the binder were inserted into each clamp through the lateral gaps between the top and the bottom plates (figure 1); the clamps were subsequently closed pinning the ends of the binder between the plates and the spikes. Subsequently, self-locking nylon cables were inserted through the metal loop of each clamp spanning the fascial defect. The cable ties were tightened enough to secure the clamps in position without sutures or any surgical procedure (figure 2).

\section{Patient management}

The research team assessed each patient every 12 hours. A data safety monitor reviewed all adverse events in a blinded fashion and notified the principal investigator (PI). The baseline width of the fascial defect was ascertained on three different locations, namely $2 \mathrm{~cm}$ below the most cranial point of the incision, at the midpoint of the incision, and $2 \mathrm{~cm}$ above the most caudal point of the incision. The lengths of the laparotomy incisions were also recorded.

The PI gradually tightened the cable ties at the bedside during daily assessments ensuring that adequate tension was maintained on the cables. Apart from that, the general care of the patients in both groups was at the discretion of the attending surgeon, including the decision to close or to keep the abdomen open on subsequent operations and the surgical technique. The attending surgeons removed the device by simply cutting the cable ties with scissors. In case of continuation of the open abdomen strategy after a take-back to the operating room, the attending surgeons reapplied the ABThera system in all patients. Afterwards, the PI reapplied the device to the appropriate patients at the bedside. Individual patient participation in the study ended when no more plans for additional intra-abdominal procedures were considered by the attending surgeons. In those cases, the fascial defect was managed by one of the following methods: primary fascial suture, fascial closure with the use of mesh (biologic or synthetic), relaxation incisions to advance the fascia prior to closure, component separation techniques with or without mesh, skin closure only with or without mesh, and delayed planned ventral hernia with skin graft.

\section{Statistical analysis}

The intention-to-treat principle was applied to analysis of outcomes. Baseline characteristics and the outcomes are described using means and SD for continuous data, and counts 


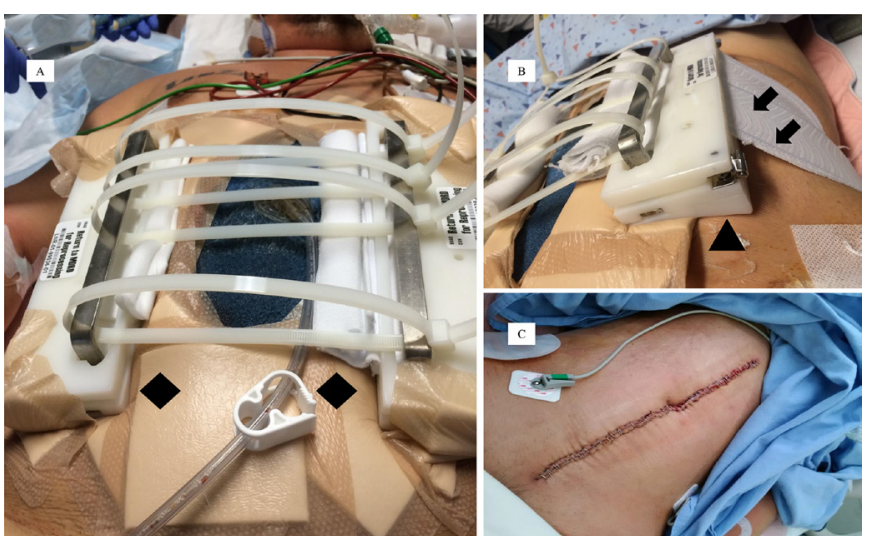

Figure 2 (A) The new device on a patient. The cable ties were tightened to secure the clamps in position without sutures. Diamonds depict the silicone foam dressings to prevent potential damage to the skin caused by the device. (B) Arrows depict the elastic abdominal binder coming around the patient's back on the left side and entering the lateral aspect of the device. Triangle depicts the $20^{\circ}$ inclination on the underside of the bottom plate engaging the left rectus abdominis muscle. (C) The final aspect of a device group patient's abdominal wall after primary fascial closure.

and proportions for categorical data. The primary outcome was compared between groups using the $\chi^{2}$ test. The treatment effect was expressed as the difference in proportions with successful closure and the 95\% CI. All analyses were performed using SAS (Statistical Analysis System) V.9.4 (SAS Institute); data are reported as mean $\pm \mathrm{SD}$. All tests were two sided and statistical significance was defined with the $\mathrm{p}$ value $<0.05$.

\section{RESULTS}

Forty eligible patients were initially enrolled in the study between January 2018 and July 2019 (figure 3). However, two patients had to be excluded from the study after randomization, both patients belonged to the control group. In one case, the family revoked consent because the patient was randomized to the control group; unfortunately, this patient died weeks later with an open abdomen. In the other case, the patient died shortly after randomization. Hence, 38 patients were investigated, 20 in the device group and 18 in the control group. Results showed that the demographic data of the two groups were comparable (table 1).

Primary closure of the abdominal wall through direct suture of the fascia without mesh or component separation was achieved in 17 patients (85\%) in the device group, whereas only 10 patients $(55.6 \%)$ in the control group had the abdominal wall fascia closed through direct fascial suture $(p=0.0457)$. Device group patients were $53 \%$ more likely to experience primary fascial closure by direct suture than the control group patients (risk ratio $=1.53$; exact $95 \%$ CI 0.9943 to 2.7976 ). One patient in the device group required component separation and mesh for fascial closure and two other patients were treated with skin grafts and planned ventral hernias; one of those patients died from severe head injury. In contrast, four patients in the control group required component separation and mesh for fascial closure and four other patients were managed with planned ventral hernias. The number of days between the randomization of the patient and the day of the final decision pertaining to the definitive solution to the open abdomen was similar in the control and the device groups; respectively $4.0 \pm 3.4$ days versus $4.9 \pm 4.7$ days $(p=0.5228)$. The number of operations during this time period was similar between control and device group patients; respectively $1.3 \pm 0.6$ operations versus $1.5 \pm 0.8$ operations $(\mathrm{p}=0.372)$.

The mean baseline width of the fascial defects measured at the midpoint of the incisions was similar between the control group and the device group; respectively $12.71 \pm 2.7 \mathrm{~cm}$ versus $12.53 \pm 4.2 \mathrm{~cm}(\mathrm{p}=0.1237)$. The mean baseline area of the defects was also similar between the control and the device groups; respectively $264.9 \pm 56.6 \mathrm{~cm}^{2}$ versus $315.0 \pm 116.2 \mathrm{~cm}^{2}$ $(p=0.0588)$. However, the final area and the final width of the fascial defects of patients in the device group reduced significantly compared with baseline; respectively $315.0 \pm 116.2 \mathrm{~cm}^{2}$

2225 Trauma patients and 1425 acute care surgery patients (January 2018 - July 2019)

\begin{tabular}{|c|c|}
\hline & $\begin{array}{l}\text { Excluded patients who did not undergo laparotomy: } \\
\text { 1. Trauma; } n=2095 \\
\text { 2. Acute care surgery; } n=1284\end{array}$ \\
\hline \multicolumn{2}{|c|}{$\begin{array}{l}\text { Trauma laparotomies: } \mathrm{n}=130 \\
\text { Acute care surgery laparotomies: } \mathrm{n}=141\end{array}$} \\
\hline & $\begin{array}{l}\text { Excluded patients without an open abdomen: } \\
\text { 1. Trauma; } n=99 \\
\text { 2. Acute care surgery; } n=112\end{array}$ \\
\hline \multicolumn{2}{|c|}{ Open abdomens: $\mathrm{n}=60(20.1 \%)$} \\
\hline & $\begin{array}{l}\text { Excluded patients: } \\
\text { 1. Declined consent by family; } \mathrm{n}=15 \\
\text { 2. } * \mathrm{BMI}>40 \text {; pre-existing ventral hernia; traumatic hernia; } \mathrm{n}=5 \\
\text { 3. Consent revoked by family after result of randomization; } \mathrm{n}=1 \\
\text { 4. Patient died after randomization; } \mathrm{n}=1\end{array}$ \\
\hline
\end{tabular}

Total number of patients included in the study: $n=38$

Figure 3 Patient enrollment flow chart. BMI, body mass index. 


\begin{tabular}{llll}
\hline Table 1 & Patient characteristics & & \\
\hline & $\begin{array}{l}\text { Device group } \\
20(52.6 \%)\end{array}$ & $\begin{array}{l}\text { Control group } \\
18(47.4 \%)\end{array}$ & P value \\
\hline Demographics & $46.3 \pm 24.6$ & $56.8 \pm 20.2$ & 0.1630 \\
\hline Age, mean \pm SD & $28.2 \pm 5.6$ & $26.4 \pm 5.0$ & 0.3071 \\
\hline BMI, mean \pm SD & $17(85.0)$ & $11(61.1)$ & 0.1440 \\
\hline Male, $\mathrm{n}(\%)$ & $12(60.0)$ & $7(38.9)$ & 0.1937 \\
\hline Trauma patient, $\mathrm{n}(\%)$ & $9(75.0)$ & $3(42.9)$ & 0.3261 \\
\hline Penetrating injury, $\mathrm{n}(\%)$ & & & \\
\hline Indication for the open abdomen & & $3(16.7)$ & 0.6968 \\
\hline Anatomic reason, $\mathrm{n}(\%)$ & $5(25.0)$ & $13(72.2)$ & 1.000 \\
\hline Physiologic reason, $\mathrm{n}(\%)$ & $15(75.0)$ & $12(66.7)$ & 0.1171 \\
\hline Logistic reason, $\mathrm{n}(\%)$ & $18(90.0)$ & & \\
\hline Medical history & & $4(22.2)$ & 1.000 \\
\hline Smoker, $\mathrm{n}(\%)$ & $4(20.0)$ & $1(5.6)$ & 0.941 \\
\hline Previous laparotomy, $\mathrm{n}(\%)$ & $1(5.0)$ & & \\
\hline Clinical status at the time of randomization & & & 0.3577 \\
\hline Peritonitis/sepsis, $\mathrm{n}(\%)$ & $5(25.0)$ & $7(38.9)$ & 0.6062 \\
\hline Ostomy, $\mathrm{n}(\%)$ & $3(15.0)$ & $1(5.6)$ & 0.3577 \\
\hline Vasopressors, $\mathrm{n}(\%)$ & $15(75.0)$ & $11(61.1)$ & 0.9442 \\
\hline Coagulopathy, $\mathrm{n}(\%)$ & $8(40.0)$ & $7(38.9)$ & 0.2391 \\
\hline AKI, $\mathrm{n}(\%)$ & $8(40.0)$ & $4(22.2)$ & 0.7591 \\
\hline APACHE II, mean $\pm \mathrm{SD}$ & $20.6 \pm 7.6$ & $21.2 \pm 5.5$ & 0.7130 \\
\hline Mannheim Peritonitis Index, mean $\pm \mathrm{SD}$ & $16.5 \pm 10.3$ & $18.4 \pm 8.5$ \\
\hline "Some & & & \\
\hline
\end{tabular}

*Some patients had more than one reason to leave the abdomen open, thus the number of indications is larger than the number of patients enrolled in the study.

$\mathrm{AKI}$, acute kidney injury (twofold to threefold increase in serum creatinine and or urinary output $<0.5 \mathrm{~mL} / \mathrm{kg}$ for 12 hours); APACHE II, Acute Physiology and Chronic Health Evaluation II at admission to the intensive care unit after laparotomy; BMI, body mass index.

versus $218.6 \pm 150.5 \mathrm{~cm}^{2}(\mathrm{p}=0.0053)$ and $12.53 \pm 4.2 \mathrm{~cm}$ versus $9.32 \pm 4.7 \mathrm{~cm}(\mathrm{p}=0.005)$. In contrast, there were no significant reductions in those measurements in control group patients compared with baseline (figure 4).

The degree of fixation of the abdominal viscera to the abdominal wall at the time of the definitive management of the fascial defect was similar between the two groups. ${ }^{36}$ Twelve patients in the control group and 13 patients in the device group were graded as having no fixation (classes $1 \mathrm{~A}$ and $1 \mathrm{~B}$ ). Six patients in each group were categorized as developing fixation, thus rated classes $2 \mathrm{~A}$ and $2 \mathrm{~B}$. One remaining patient in the device group had an enteroatmospheric fistula and a frozen abdomen; this patient was rated as class 4. Comparably, the Mannheim Peritonitis Index scores were also similar between the groups; $16.5 \pm 10.3$ in the control group and $18.4 \pm 8.5$ in the device group $(\mathrm{p}=0.713)$.

The volume of crystalloid solution administered during the elapsed time between the randomization and the final procedure for the definitive management of the open abdomen was similar between the control and the device groups; respectively 12 $193 \pm 7789 \mathrm{~mL}$ versus $13227 \pm 11947 \mathrm{~mL}(\mathrm{p}=0.7537)$. Comparably, the cumulative fluid balance on the day of the final decision pertaining to the definitive solution to the open abdomen was also similar between the control and the device groups; respectively $12226 \pm 666 \mathrm{~mL}$ versus $13521 \pm 125 \mathrm{~mL}(\mathrm{p}=0.691)$. Lactate levels from arterial blood samples obtained at randomization were similar between the two groups; $2.9 \pm 1.7 \mathrm{mmol} / \mathrm{L}$ in the control group versus $3.0 \pm 3.3 \mathrm{mmol} / \mathrm{L}$ in the device group $(\mathrm{p}=0.901)$.

Three patients in the device group and two patients in the control group required an ostomy during the management of the open abdomen. The reasons for the ostomies were related to fistula formation. An opening was created in the elastic abdominal binder to accommodate the ostomy in device group patients. Concerning the secondary outcomes, there was one incidence of a blister on the anterior abdominal wall potentially caused by the new device. The blister was treated with topical petroleum jelly (Vaseline Covidien, Dublin, Ireland) and covered with gauze, no additional treatment was required. The new device did not cause any injuries to the fascia. There were no cases of abdominal compartment syndrome with the new device. Moreover, there were no cases of fascial dehiscence in device group patients up to the seventh postoperative day after primary fascial closure.
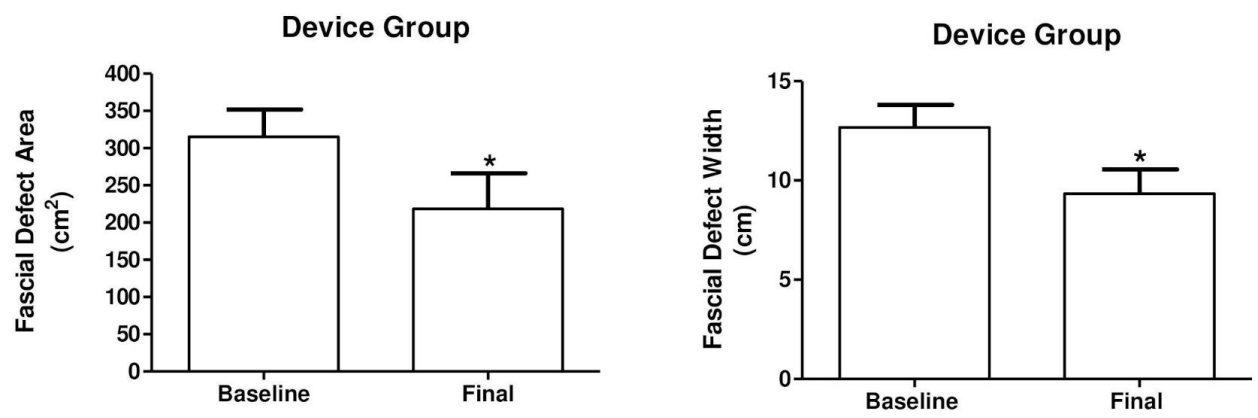

Control Group
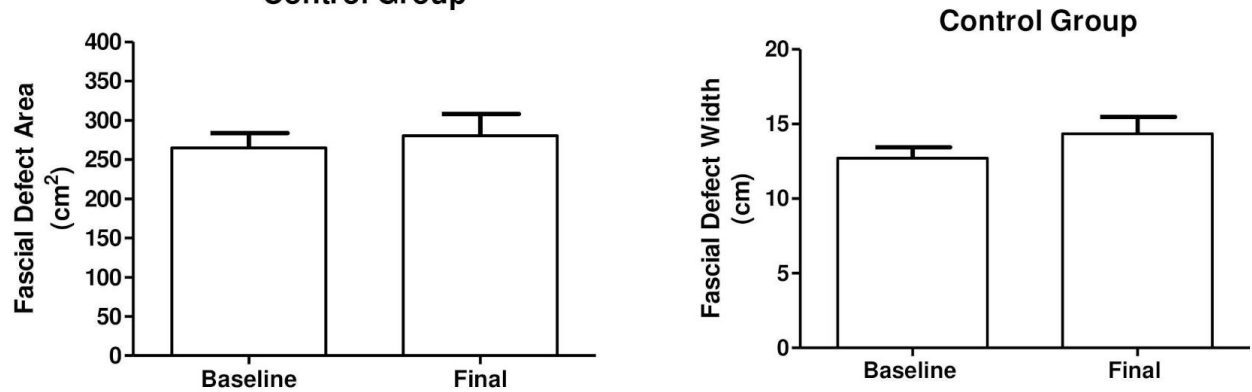

Figure 4 Area and width of the fascial defects baseline and final. 


\section{DISCUSSION}

The preferred outcome in the management of the open abdomen is to restore the integrity of the abdominal wall through primary suture of the fascial defect. ${ }^{1215-17192123-262831-34}$ Our study showed that the use of the new device combined with a negative pressure system resulted in a higher rate of primary fascial closure than the use of the negative pressure therapy system alone. The new device also preserved the integrity of the fascial edges and facilitated continuous access to the abdominal cavity. More significant, however, was the fact that those results were achieved through a non-invasive procedure applied at the bedside.

Previous research showed that mechanical forces applied to the skin of the abdomen can be effectively transmitted to the fascia across the three layers of the subcutaneous tissue of the anterior abdominal wall. ${ }^{37-40}$ This process initially involves the fibrous septa in the superficial layer and the stratified bundles of collagen in the membranous layer. ${ }^{37}$ The collagen bundles are fused with the linea alba medially, and are particularly resistant to transverse and longitudinal traction. Ultimately, the mechanical forces reach the fascia of the abdominal wall muscles through tightly packed collagen network present in the deep subcutaneous layer. ${ }^{37} 3840$

The conception of the device was grounded on the notion that the configuration of the abdominal cavity is similar to an elliptical cylinder. The circumferential stress created on the walls of a cylinder is known as hoop stress $\left(\sigma={ }^{\mathrm{PR}} / \mathrm{t}\right.$; where $\mathrm{P}=$ intraabdominal pressure; $\mathrm{R}=$ abdominal radius; $\mathrm{t}=$ =wall thickness) ${ }^{41}{ }^{42}$ Therefore, we developed a mathematical formula to assess the correlation between the hoop stress and the force vectors generated on the self-locking cables $\left(\sigma_{\alpha}=\frac{\mathrm{F}}{\mathrm{w}^{*} \mathrm{t}^{*} \mathrm{e} \mu(\beta-\alpha)}\right.$; where $\mathrm{F}=$ stress on the cables; $\mathrm{w}=$ width of the elastic binder; $\mathrm{t}=$ wall thickness; $\mu=$ coefficient of friction between the elastic binder and the skin). In an experimental porcine model, we attached a digital scale to the edge of the fascial defect and determined the midline traction force required to reapproximate the fascia in the midline completely. We subsequently placed the rigid polyurethane plates of the device on top of the animal's anterior abdominal wall. The plates were positioned along the topography of the rectus abdominis muscles parallel to the fascial defect. The self-locking cables were tightened as described in the present clinical trial. Our findings showed that the midline traction force generated at the widest portion of the fascial defect by tightening the cables was $196.3 \mathrm{~N}$ (44.12 pound force (lbf)). The subcutaneous tissue acted as interconnected load-transmitting structure despite the lack of direct contact between the plates and the fascia. Interestingly, that traction force was three times greater than the force required for suture pull-out in the linea alba as per previously published biomechanical research. ${ }^{43}$ However, given the rectangular configuration of the rigid polyurethane plates the total force was distributed along the anterior abdominal wall resulting in a midline traction force of $2.79 \mathrm{~N} / \mathrm{cm}^{2}$, avoiding damage to the abdominal wall (figure 5).

The literature shows higher primary fascial closure rates when vacuum-assisted devices are used in conjunction with techniques that provide gradual midline dynamic tension of the abdominal wall fascia. ${ }^{13-16} 22-34$ This approach decreases the degree of reshaping that occurs in the abdominal cavity as a result of a severed linea alba, and reduces the fascial gap in open abdomens. ${ }^{44-46}$ However, the favorable results of that combined approach are limited by the gradual lateralization of the oblique muscles, the outward buckling of the rectus abdominis muscles, and the increase in intra-abdominal pressure. ${ }^{478}$ Failure to overcome those limitations leads to the enlargement of the fascial defect and loss of abdominal domain. The technology described

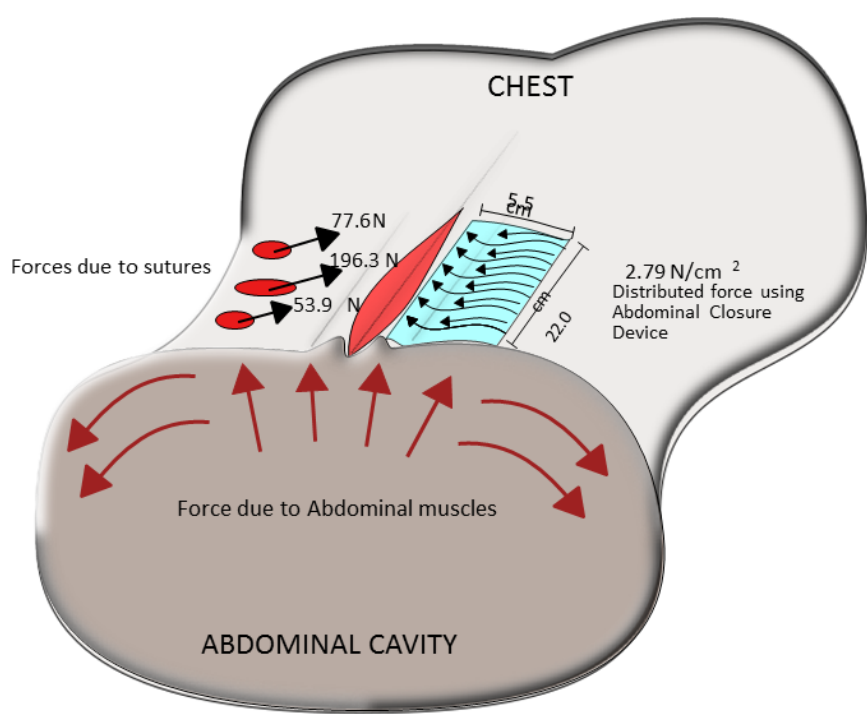

Figure 5 Force distribution and corresponding midline traction of the abdominal wall fascia with the new device. $\mathrm{N}$, newtons.

herein enhances the efficacy of the gradual midline dynamic tension concept by engaging the entire abdominal wall. Moreover, the rigidity of the polyurethane plates positioned on top of the rectus abdominis muscles counteracts the outward buckling of those muscles during fascial reapproximation, helping to preserve the original elliptical cylinder configuration of the abdominal cavity and to prevent loss of abdominal domain. Lastly, the non-invasive feature of the new device and the recourse of concomitantly interposing a plastic barrier between the fascia and abdominal viscera could potentially reduce adhesion formation between those structures.

This study has several limitations. First, the sample size was restricted by feasibility issues related to the allotted period for completion of this study by the Research Ethics Board and the low yearly number of open abdomen patients in our institution. Consequently, we combined patients with open abdomens related to both trauma and non-trauma laparotomies, notwithstanding previous evidence of disparate rates of primary fascial closure between those groups. ${ }^{20} 49$ Nonetheless, the homogeneity of the two groups in our study helped to mitigate that limitation. Second, given that the standard management of the open abdomen in our institution calls for the use of negative pressure therapy system only, we were unable to perform a head-to-head comparison between our device and different invasive methods currently available for gradual fascial reapproximation. Third, in this pilot study, we did not implement a standardized patient management protocol. This limitation could interfere with the comparability of the results. Alternatively, all elements in the management of the open abdomen were at the discretion of the attending surgeon including take-back operation plans and the technique used for the definitive management of the fascial defect. ${ }^{27}$ We anticipate, for the most part, that a recently started multicenter clinical trial will help address the aforementioned limitations. That trial is in progress with the production version of the device used in the present study. Lastly, the detection of additional benefits and potential hazards related to the use of our device was limited by a short follow-up period of 7 days.

\section{CONCLUSION}

In conclusion, this study demonstrated that a non-invasive technology applied externally on the abdominal wall promoted 
reapproximation of the fascia in the midline. The new device enabled continuous access to the peritoneal cavity, preserved the integrity of the fascia, and improved primary fascial closure rate compared with negative pressure therapy system only. Further investigation is necessary comparing this technology to current invasive techniques for gradual fascial reapproximation.

Acknowledgements The authors would like to thank Sandy Trpcic, Trauma Research Manager at St Michael's Hospital, and the research assistants for providing support in this study's data collection and ensuring that research ethics protocols were strictly complied.

Contributors JBRN: devised the technology, conceived the study (principal investigator), data interpretation and led the elaboration of the article, literature search, and critical revision. BGC: data acquisition, data interpretation, literature search, contributed to the elaboration of the article.

Funding This study was supported by the Canadian Institutes of Health Research (CIHR)-Proof of Principle Program-Phase 1 Grant (201502PPP-345409-PPPCEAJ-259794).

Competing interests JBRN (corresponding author of the article) was the inventor of the device used in the study and holds a patent on the device (PCT/ CA2016/050124)

Patient consent for publication Not required.

Ethics approval This study was approved by St Michael's Hospital Research Ethics Board under protocol number REB14-314.

Provenance and peer review Not commissioned; externally peer reviewed.

Data availability statement Data are available upon reasonable request.

Open access This is an open access article distributed in accordance with the Creative Commons Attribution Non Commercial (CC BY-NC 4.0) license, which permits others to distribute, remix, adapt, build upon this work non-commercially, and license their derivative works on different terms, provided the original work is properly cited, appropriate credit is given, any changes made indicated, and the use is non-commercial. See: http://creativecommons.org/licenses/by-nc/4.0/.

\section{REFERENCES}

1 Dubose JJ, Scalea TM, Holcomb JB, Shrestha B, Okoye O, Inaba K, Bee TK, Fabian TC, Whelan J, Ivatury RR, et al. Open abdominal management after damage-control laparotomy for trauma: a prospective observational American association for the surgery of trauma multicenter study. J Trauma Acute Care Surg 2013;74:113-20.

2 Hatch QM, Osterhout LM, Podbielski J, Kozar RA, Wade CE, Holcomb JB, Cotton BA. Impact of closure at the first take back: complication burden and potential overutilization of damage control laparotomy. J Trauma 2011;71:1503-11.

3 Miller RS, Morris JA, Diaz JJ, Herring MB, May AK. Complications after 344 damagecontrol open celiotomies. J Trauma 2005;59:1365-74.

4 Sava J, Alam HB, Vercruysse G, Martin M, Brown CVR, Brasel K, Moore EE, Ciesla D, Inaba K, et al. Western Trauma Association Critical Decisions in Trauma Committee. Western trauma association critical decisions in trauma: management of the open abdomen after damage control surgery. J Trauma Acute Care Surg 2019;87:1232-8.

5 Watson JJJ, Nielsen J, Hart K, Srikanth P, Yonge JD, Connelly CR, Kemp Bohan PM, Sosnovske $\mathrm{H}$, Tilley $\mathrm{BC}$, van Belle $\mathrm{G}$, et al. Damage control laparotomy utilization rates are highly variable among level I trauma centers: pragmatic, randomized optimal platelet and plasma ratios findings. J Trauma Acute Care Surg 2017;82:481-8.

6 Demetriades D, Salim A. Management of the open abdomen. Surg Clin North Am 2014:94:131-53.

7 Rotondo MF, Schwab CW, McGonigal MD, Phillips GR, Fruchterman TM, Kauder DR, Latenser BA, Angood PA. 'Damage control': an approach for improved survival in Exsanguinating penetrating abdominal injury. J Trauma 1993;35:375-82.

8 Rotondo MF, Zonies DH. The damage control sequence and underlying logic. Surg Clin North Am 1997;77:761-77.

9 Stone HH, Strom PR, Mullins RJ. Management of the major coagulopathy with onset during laparotomy. Ann Surg 1983;197:532-5.

10 Chabot E, Nirula R. Open abdomen critical care management principles: resuscitation, fluid balance, nutrition, and ventilator management. Trauma Surg Acute Care Open 2017:2:e000063-9.

11 Rezende-Neto J, Rice T, Abreu ES, Rotstein O, Rizoli S. Anatomical, physiological, and logistical indications for the open abdomen: a proposal for a new classification system. World J Emerg Surg 2016;11:28.

12 Chen Y, Ye J, Song W, Chen J, Yuan Y, Ren J. Comparison of outcomes between early fascial closure and delayed abdominal closure in patients with open abdomen: a systematic review and meta-analysis. Gastroenterol Res Pract 2014;2014:1-8.

13 Diaz JJ, Dutton WD, Ott MM, Cullinane DC, Alouidor R, Armen SB, Bilanuik JW, Collier BR, Gunter OL, Jawa R, et al. Eastern Association for the Surgery of Trauma: a review of the management of the open abdomen--part 2 "Management of the open abdomen". J Trauma 2011;71:502-12.

14 Hougaard HT, Ellebaek M, Holst UT, Qvist N. The open abdomen: temporary closure with a modified negative pressure therapy technique. Int Wound I 2014;11 Suppl 1:13-16.

15 Cothren CC, Moore EE, Johnson JL, Moore JB, Burch JM. One hundred percent fascial approximation with sequential abdominal closure of the open abdomen. Am J Surg 2006:192:238-42.

16 Gäddnäs F, Saarnio J, Ala-Kokko T, Laurila J, Koivukangas V. Continuous retention suture for the management of open abdomen: a high rate of delayed fascial closure Scand J Surg 2007;96:301-7.

17 Garner GB, Ware DN, Cocanour CS, Duke JH, McKinley BA, Kozar RA, Moore FA. Vacuum-assisted wound closure provides early fascial reapproximation in trauma patients with open abdomens. Am J Surg 2001;182:630-8.

18 Boele van Hensbroek P, Wind J, Dijkgraaf MGW, Busch ORC, Goslings JC, Carel Goslings J. Temporary closure of the open abdomen: a systematic review on delayed primary fascial closure in patients with an open abdomen. World I Surg 2009;33:199-207

19 Coccolini F, Biffl W, Catena F, Ceresoli M, Chiara O, Cimbanassi S, Fattori L, Leppaniem A, Manfredi R, Montori G, et al. The open abdomen, indications, management and definitive closure. World J Emerg Surg 2015;10:32.

20 Coccolini F, Roberts D, Ansaloni L, Ivatury R, Gamberini E, Kluger Y, Moore EE, Coimbra $R$, Kirkpatrick AW, Pereira BM, et al. The open abdomen in trauma and non-trauma patients: WSES guidelines. World J Emerg Surg 2018;13:7

21 Hu P, Uhlich R, Gleason F, Kerby J, Bosarge P. Impact of initial temporary abdominal closure in damage control surgery: a retrospective analysis. World J Emerg Surg 2018; 13:43

22 Cipolla J, Stawicki SP, Hoff WS, McQuay N, Hoey BA, Wainwright G, Grossman MD. A proposed algorithm for managing the open abdomen. Am Surg 2005;71:202-7.

23 Fantus RJ, Mellett MM, Kirby JP. Use of controlled fascial tension and an adhesion preventing barrier to achieve delayed primary fascial closure in patients managed with an open abdomen. Am J Surg 2006:192:243-7.

24 Hadeed JG, Staman GW, Sariol HS, Kumar S, Ross SE. Delayed primary closure in damage control laparotomy: the value of the Wittmann patch. Am Surg 2007:73:10-12.

25 Miller PR, Thompson JT, Faler BJ, Meredith JW, Chang MC. Late fascial closure in lieu of ventral hernia: the next step in open abdomen management. J Trauma 2002;53:843-9.

26 Mukhi AN, Minor S. Management of the open abdomen using combination therapy with ABRA and ABThera systems. Can J Surg 2014;57:314-9.

27 Pommerening MJ, DuBose JJ, Zielinski MD, Phelan HA, Scalea TM, Inaba K, Velmahos GC, Whelan JF, Wade CE, Holcomb JB, et al. Time to first take-back operation predicts successful primary fascial closure in patients undergoing damage control laparotomy. Surgery 2014;156:431-8.

28 Stonerock CE, Bynoe RP, Yost MJ, Nottingham JM. Use of a vacuum-assisted device to facilitate abdominal closure. Am Surg 2003;69:1030-4.

29 Tieu BH, Cho SD, Luem N, Riha G, Mayberry J, Schreiber MA. The use of the Wittmann patch facilitates a high rate of fascial closure in severely injured trauma patients and critically ill emergency surgery patients. J Trauma 2008;65:865-70.

30 Wondberg D, Larusson HJ, Metzger U, Platz A, Zingg U. Treatment of the open abdomen with the commercially available vacuum-assisted closure system in patients with abdominal sepsis: low primary closure rate. World I Surg 2008:32:2724-9.

31 Fortelny RH, Hofmann A, Gruber-Blum S, Petter-Puchner AH, Glaser KS. Delayed closure of open abdomen in septic patients is facilitated by combined negative pressure wound therapy and dynamic fascial suture. Surg Endosc 2014;28:735-40.

32 Kafka-Ritsch R, Zitt M, Schorn N, Stroemmer S, Schneeberger S, Pratschke J, Perathoner A. Open abdomen treatment with dynamic sutures and topical negative pressure resulting in a high primary fascia closure rate. World I Surg 2012;36:1765-71.

33 Petersson U, Acosta S, Björck M. Vacuum-assisted wound closure and mesh-mediated fascial traction--a novel technique for late closure of the open abdomen. World I Surg 2007:31:2133-7.

34 Salman AE, Yetișir F, Aksoy M, Tokaç M, Yildirim MB, Kiliç M. Use of dynamic wound closure system in conjunction with vacuum-assisted closure therapy in delayed closure of open abdomen. Hernia 2014;18:99-104.

35 Lancaster GA, Dodd S, Williamson PR. Design and analysis of pilot studies: recommendations for good practice. J Eval Clin Pract 2004;10:307-12

36 Kirkpatrick AW, Roberts DJ, De Waele J, Jaeschke R, Malbrain MLNG, De Keulenaer B, Duchesne J, Bjorck M, Leppaniemi A, Ejike JC, et al. Intra-Abdominal hypertension and the abdominal compartment syndrome: updated consensus definitions and clinical practice guidelines from the world Society of the abdominal compartment syndrome. Intensive Care Med 2013;39:1190-206.

37 Lancerotto L, Stecco C, Macchi V, Porzionato A, Stecco A, De Caro R. Layers of the abdominal wall: anatomical investigation of subcutaneous tissue and superficial fascia. Surg Radiol Anat 2011;33:835-42.

38 Lyons M, Winter DC, Simms CK. Mechanical characterisation of porcine rectus sheath under uniaxial and biaxial tension. J Biomech 2014;47:1876-84. 
39 Piérard GE, Piérard S, Delvenne P, Piérard-Franchimont C. In vivo evaluation of the skin tensile strength by the suction method: pilot study coping with hysteresis and creep extension. ISRN Dermatol 2013;2013:1-7.

40 Silver FH, Siperko LM, Seehra GP. Mechanobiology of force transduction in dermal tissue. Skin Res Technol 2003:9:3-23.

41 Shoghi K, Rao HV, Barrans SM. Stress in a flat section band clamp. Proc Inst Mech Eng C J Mech Eng Sci 2003;217:821-30.

42 Thomas GB, Finney RL. Vectors. Calculus and analytic geometry. Boston, MA: AddisonWesley Publishing Company Inc, 1993:697-758.

43 Campbell JA, Temple WJ, Frank CB, Huchcroft SA. A biomechanical study of suture pullout in linea alba. Surgery 1989;106:888-92.

44 Blaser AR, Björck M, De Keulenaer B, Regli A. Abdominal compliance: a bench-tobedside review. J Trauma Acute Care Surg 2015;78:1044-53.

45 Malbrain MLNG, Roberts DJ, De Laet I, De Waele JJ, Sugrue M, Schachtrupp A, Duchesne J, Van Ramshorst G, De Keulenaer B, Kirkpatrick AW, et al. The role of abdominal compliance, the neglected parameter in critically ill patients - a consensus review of 16. Part 1: definitions and pathophysiology. Anaesthesiol Intensive Ther 2014;46:392-405.

46 Malbrain MLNG, Peeters Y, Wise R. The neglected role of abdominal compliance in organ-organ interactions. Crit Care 2016;20:67.

47 DuBay DA, Choi W, Urbanchek MG, Wang X, Adamson B, Dennis RG, Kuzon WM, Franz MG. Incisional herniation induces decreased abdominal wall compliance via oblique muscle atrophy and fibrosis. Ann Surg 2007;245:140-6.

48 Lien SC, Hu Y, Wollstein A, Franz MG, Patel SP, Kuzon WM, Urbanchek MG. Contraction of abdominal wall muscles influences size and occurrence of incisional hernia. Surgery 2015:158:278-88.

49 Tsuei BJ, Skinner JC, Bernard AC, Kearney PA, Boulanger BR. The open peritoneal cavity: etiology correlates with the likelihood of fascial closure. Am Surg 2004; 70:652-6. 